\title{
LE pH DANS LE TUBE DIGESTIF DES OISEAUX
}

\author{
Clair HERPOL et G. VAN GREMBERGEN \\ Laboratoire de Zoophysiologie, Université de Gand (Belgique)
}

\section{SOMMAIRE}

Le $\mathrm{pH}$ du tube digestif ayant un rôle déterminant dans l'efficacité des enzymes, il était nécessaire, vu la diversité des données de la littérature, de revoir cette question dans le cadre d'une étude sur la digestion des oiseaux.

Le $\mathrm{pH}$ des différentes régions du tractus digestif de poulets "White Leghorn " a été déterminé avec l'électrode Beckman $n^{\circ} 39042$ adaptée au $\mathrm{pH}$ mètre modèle Ioo de la "Photovolt Electronic Corporation ", l'électrode no 39168 étant utilisée comme référence.

Des mesures in vivo ont été effectuées sur diverses espèces d'oiseaux.

Comparativement aux chiffres connus, nous obtenons :

I $^{\circ}$ Un pH plus élevé dans le jabot ;

$2^{\circ}$ Un degré d'acidité supérieur dans l'estomac qui laisse supposer, contrairement à ce que l'on accepte généralement, une action efficace de la pepsine dans le gésier ;

$3^{\circ} \mathrm{Un} \mathrm{pH}$ plus élevé dans toutes les régions de l'intestin.

Un des aspects les plus importants de la digestion est certes la transformation enzymatique des constituants nutritifs complexes en produits simples susceptibles d'être absorbés. Mais l'activité enzymatique étant entre autres conditionnée par la concentration en ions hydrogènes, il apparaît clairement que le pH des différents secteurs du tube digestif a un rôle déterminant dans l'efficacité de la digestion.

TABLEAU I

Aperçu des données de littérature

Le $\mathrm{pH}$ post mortem dans le tube digestif de Gallus domesticus

\begin{tabular}{|c|c|c|c|c|c|c|c|c|}
\hline & Jabot & $\begin{array}{c}\text { Estomac } \\
\text { Glan- } \\
\text { dulaire }\end{array}$ & Gésier & $\begin{array}{l}\text { Duo- } \\
\text { denum }\end{array}$ & $\begin{array}{c}\text { Ileum } \\
1^{\text {re }} \text { partie }\end{array}$ & Ileum & Rectum & Caecum \\
\hline 1931 Mc. LaUghlin .... & - & 5,59 & 3,39 & 6,29 & \multicolumn{2}{|c|}{$6,2,2$} & 一 & 1,92 \\
\hline 1933 AsCHCRAFT . . . . . . & - & - & 一 & 5,96 & \multicolumn{2}{|c|}{7,13} & 7,26 & 7,06 \\
\hline 1933 Musseirl e.a. . . . . & - & 4,8 & 2,9 & 6,2 & 6,2 & 6,9 & $\longrightarrow$ & - \\
\hline 1935 Mayew . . . . . . . . & !, 72 & 4,50 & - & 6,11 & 0,05 & $6,50-6,54$ & 一 & 6,70 \\
\hline $1935 \mathrm{KERR}$ e.a........ & 4,0 & 3,6 & 3,0 & 6,3 & 6,7 & 7,0 & 6,7 & $7,0-7,2$ \\
\hline 1936 HELLER e.a. . . . . & 4,14 & 3,61 & 2,99 & 5,97 & $5,9 \prime$ & 7,21 & 6,62 & 6,98 \\
\hline $19^{\prime} 2$ (a) FARNER . . . . . & 4,51 & 4,10 & 2,60 & $5,76-6,01$ & $5,78-5,90$ & $6,27-6,42$ & 6,26 & 5,71 \\
\hline 1944 BUChNER e.a..... & - & $4,3-4,1$ & $2,7-3,6$ & $6,3-6,1$ & - & - & - & $\longrightarrow$ \\
\hline $19 \div 6$ Vonk e.a. . . . . . . & $4,0-5,0$ & $1,85-5,50$ & $2,1,0-3,60$ & $5,20-6,05$ & - & - & - & - \\
\hline 1955 Hewit e.a... & $\iota_{1}, 67$ & 4,18 & $2,9^{\prime} t$ & 6,13 & 6,29 & 6,58 & 6,82 & $6,1^{\prime}$ \\
\hline 1956 HoRTon-SMITH e.a. & $t_{1}, 1-6,2$ & - & $2,9-3,2$ & $5,1-6,2$ & 5,9 & $-6,1$ & 一 & $5,8-6,2$ \\
\hline 1958 March e.a....... & - & $\longrightarrow$ & - & $6,2 \div-6,51$ & $6,0^{\prime}-6,37$ & $|6,92-7,39|$ & - & $5,89-6,37$ \\
\hline 1960 HWANG $\ldots \ldots \ldots$ & 一 & $2,89-4,14$ & $2,72-4,00$ & $6,08-7,15$ & $6,10-7,28$ & $5,88-7,42$ & - & - \\
\hline
\end{tabular}


Les quelques auteurs, ayant dirigé leurs recherches vers le problème du $\mathrm{pH}$ dans le tube digestif des oiseaux, ont publié des résultats fort divergents (tableau I).

Les physiologistes peuvent difficilement expliquer le fait que la digestion enzymatique des oiseaux est particulièrement effective et que par contre les valeurs du $\mathrm{pH}$, dans une partie déterminée du tube digestif, sont parfois fort divergentes de l'optimum nécessaire à l'enzyme sécrété à cet endroit.

Il ressort, par exemple, du tableau I qu'il est difficile de localiser l'action de la pepsine.

Au début d'une étude sur la digestion chez les oiseaux, il nous a donc paru utile d'orienter nos recherches vers le problème de la concentration en ions d'hydrogène dans le tractus digestif.

\section{MATÉRIEL, ET MÉTHODES}

Les recherches ont été effectuées chez des poulets de la race "White Leghorn ", pour la plupart de sexe masculin, nourris normalement de farine composée et de graines commerciales.

Nous mentionnerons également dans ce travail des résultats obtenus in vivo chez diverses es. pèces d'oiseaux, résultats encore incomplets, qui feront l'objet d'une publication ultérieure.

Post mortem nous nous sommes efforcés à déterminer le $\mathrm{pH}$ le plus rapidement possible. La mesure se prend en plaçant l'électrode en contact direct avec la muqueuse.

Pour les mesures in vivo l'animal ne subit aucune préparation préalable. L'électrode est simplement introduite jusque dans l'estomac par le bec maintenu entrouvert, tandis que l'électrode de référence est placée en contact avec la muqueuse de la cavité buccale.

Les mesures ont été effectuées avec une électrode Beckman $n^{0} 39042$, l'électrode ${ }^{0} 39 r 68$ étant utilisée comme référence. Ces électrodes ont été adaptées au $\mathrm{pH}$ mètre "Photovolt Electronic Corporation » modèle roo.

\section{RÉSULTATS ËT DISCUSSION}

Les premiers résultats, que nous discuterons, ont été obtenus post mortem chez des poulets de la race "White Leghorn ", nourris jusqu'à la veille del'expérience.

Nous avons pu constater, au cours d'expériences préliminaires, que l'âge n'influence pas directement le $\mathrm{pH}$ du système digestif des poulets. En effet, des recherches faites sur six catégories de poulets d'âges différents ( $\mathrm{I}$ à 8 jours, 8 à $\mathrm{I} 5$ jours, $\mathrm{I} 5$ jours à I mois, I à 2 mois et ađultes) ont montré qu'il y a autant de dispersion dans chaque groupe, qu'entre les groupes [HERPOL, (I959)], Ceci ne correspond guère aux données de Mayhew (I935) et de Vonk Brink et Postma (I946). Cependant Sturukie (I954) met les résultats de MAYHEW en doute, les différences obtenues lui paraîssant peu convaincantes; de leur côté Buchner, Insko et HENRY (I944) concluent d'une façon identique à la nôtre : le $\mathrm{pH}$ du système digestif ne varie pas avec l'âge.

Remarquons également que les données de la littérature concordent sur ce fait : le sexe n'influence pas le $\mathrm{pH}$ du tube digestif.

Dans le tableau 2, nous avons rassemblé tous nos résultats qui proviennent par conséquent de spécimens d'âges différents.

En comparant nos chiffres aux données de la littérature il apparaît que nous obtenons :

I ${ }^{\circ}$ Un $\mathrm{pH}$ plus élevé dans le jabot;

$2^{\circ}$ Une acidité de beaucoup supérieure dans les deux compartiments de l'estomac;

$3^{\circ} \mathrm{Un} \mathrm{pH}$ généralement plus élevé dans les différentes régions de l'intestin. 
La différence des résultats en ce qui concerne le jabot, trouve une explication fort simple puisque le $\mathrm{pH}$ de cet organe peut être influencé dans une large mesure par un phénomène de régurgitation acide provenant de l'estomac constaté et prouvé par $\mathrm{K}_{1} \mathrm{UG}$ [voir BRowne (I922)]. Ce phénomène est responsable des valeurs plus ou moins acides obtenues par différents auteurs.

\section{TABLEAU 2}

Le $p H$ post morten dans le tube digestif de Gallus domesticus.

\begin{tabular}{|c|c|c|c|c|}
\hline & minimum & $\begin{array}{l}\text { majorité des valeurs } \\
\text { dans l'intervalle pII entre }\end{array}$ & maximum & $\begin{array}{c}\text { Nombre } \\
\text { de mesures }\end{array}$ \\
\hline Jabot $\ldots \ldots$ & 4,1 & 6,0 et 7,0 & 7,8 & 107 \\
\hline Estomac glandulaire..... & 0,3 & 1,0 et 2,0 & 3,0 & 80 \\
\hline Gésier ............... & 0,4 & 1,5 et 2,5 & 3,8 & 81 \\
\hline Duodenum ............ & 5,6 & 6,0 et 7,0 & 7,7 & 118 \\
\hline Ileum: $1^{\text {re }}$ partie.... & 6,0 & 6,5 et 7,5 & 7,9 & 118 \\
\hline Ileum $: 2^{\mathrm{e}}$ partie $\ldots \ldots \ldots$ & 5,7 & 6,5 et 8,0 & 8,5 & 118 \\
\hline Rectum $\ldots \ldots \ldots \ldots \ldots$ & 5,3 & 6,0 et 7,5 & 8,4 & 108 \\
\hline Caecum..$\ldots \ldots \ldots \ldots$ & 5,6 & 6,5 et 7,5 & 8,1 & 100 \\
\hline
\end{tabular}

Nous sommes convaincus que la réaction du jabot propremment dit se rapproche de la neutralité.

FARNER (I942 b) attira le premier l'attention des chercheurs sur une forte diminution de l'acidité de l'estomac: suite à la mort. Il alla pus loin encore : ayant mesuré 1'acidité libre du suc gastrique, il calcula que celle-ci devait théoriquement correspondre à un $\mathrm{pH}$ I,6. Que de tels chiffres n'aient pas été obtenus, - seul VAN DOBBEN (I952) mentionne un $\mathrm{pH}$ 0,9 pour le suc gastrique du cormoran Phalacrocorax carbo) -, est dû uniquement à la méthode.

Au début de ce travail nous obtenions des chiffres tout aussi élevés que ceux que 1'on peut trouver dans la littérature. Nous savions cependant, grâce à des mesures in vivo, que ces données étaient fautives. En effet in vivo, les chiffres obtenus chez le poulet varient entre les $\mathrm{pH} 0,2$ et 2,5 avec la majorité des données (79 sur I23 mesures) dans 1'intervalle $0,5-\mathrm{I}, 5$.

Au cours d'expériences où nous avons essayé de suivre le changement du $\mathrm{pH}$ causé par la mort, nous avons pu constater qu'il est possible de réduire presque entiérement l'écart entre les valeurs obtenues in vivo et post mortem. Il suffit de veiller à réduire au minimum l'ouverture qui servira de passsage à l'électrode et d'éviter soigneusement toute contamination de l'électrode par le contenu des cellules lésées. Il nous apparaît comme peu probable de pouvoir réduire le dernier écart subsistant, car il est évident que la mort et les dégradations qu'elle entraîne (cessation de la sécrétion, annulation du potentiel responsable de la sécrétion d'acide chlorhydrique etc.) ont une part de responsabilité dans les variations post mortem de FARNER.

Les chiffres obtenus in vivo chez les poulets, concordent entièrement avec une série de résultats obtenus avec diverses espèces d'oiseaux se nourrissant fort différemment.

Jusqu'ici 36 espèces d'oiseaux de la faune belge ont été soumises à des mesures 
in vivo. Il serait cependant prématuré de discuter actuellement ces résultats encore incomplets.

De ces données on pourrait conclure que l'acidité est de nature à permettre une activité normale de la pepsine dans l'estomac glandulaire. Il n'en est pas ainsi, car la nourriture, non encore broyée, ne réside, selon les données de STEINMETzER (I924) que quelques instants dans ce compartiment.

I a digestion enzymatique par la pepsine a lieu dans le gésier, où la nourriture mêlée au suc gastrique, est placée dans des conditions d'acidité favorables pour l'enzyme. La réaction fort acide de cet organe est due aux produits de sécrétion ( $\mathrm{HCl}$, et pepsine) de l'estomac glandulaire et certes pas, comme BUDDENBRock (L956) l'a proposé, par une formation de $\mathrm{HCl}$ dans le gísier mâme.

BUDDENBROCK fut amené à une telle conclusion à la suite de la constatation faite par FARNER (I942 $a$ ) et tant d'autres, que la réaction du gésier est en règle générale plus acide que la réaction de l'estomac glandulaire.

Ces résultats sont fort compréhensibles, puisque nous avons pu constater que le $\mathrm{pH}$ du contenu du gésier ne subit qu'un changement relativement lent post-mortem.

En réalité le $\mathrm{pH}$ des deux compartiments de l'estomac est à peu près du même ordre de grandeur.

Nous avons obtenu, en ce qui concerne l'intestin, des chiffres plus élevés que ceux qui nous sont connus ; des valeurs légèrement alcalines ne représentent aucunement une exception.

N'oublions pas que la réaction du contenu de l'intestin résulte de l'interaction de différents facteurs tels que le suc acide provenant de l'estomac, la bile, le suc pancréatique, et le suc intestinal sans oublier la possibilité qu'il existe un mécanisme régulateur du pH, tel qu'il a été conçu par RoBIsson (I935), se situant au niveau de la muqueuse intestinale.

Le suc pancréatique (source principale d'enzymes) agit de façon optimale en milieu légèrement alcalin.

Selon nos données un tel milieu existe dans la majorité des cas et 1'hypothèse de STURKIE (I954) selon laquelle la haute température corporelle des oiseaux compense le $\mathrm{pH}$ trop acide de l'intestin, devient inutile.

Les caecums ont une réaction à peu près neutre, fait établi et généralement accepté depuis les recherches de MayHEw en I935.

\section{REMERCIEMENTS}

Ce travail a pu être accompli grâce à une bourse de spécialisation accordée à l'un de nous ( $\mathrm{Cl}$. H.) par l'Institut pour l'Encouragement de la Recherche Scientifique dans l'Industrie et l'Agriculture (I. R. S. I. A. ).

Rę̧u en mai 1961.

\section{SUMmary}

THE PH IN THE DIGESTIVE TRACT OF BIRDS

Many déterminations of the pII in the alimentary tract of fowls have been made (for Review of the literature, see table I). With these observations in mind we have attempted to determine the $\mathrm{pH}$ of the alimentary tract. 
Post mortem determinations were made on White Leghorn chickens. They have been allowed to feed until the day before experiment.

In vivo determinations were made within the stomach of different species. 39r68).

The hydrogen ion concentration was measured with a Beckman electrode assembly (Nos.39042.

Our post mortem results are given in table 2.

In vivo the $\mathrm{pH}$ of the stomach of chickens is, in most cases, between $\mathrm{pH} 0,5$ and $\mathrm{I}, 5$ (min.0,2 ; max. 2,5). With all species of birds, even those who are eating very different kinds of food, we have obtained very similar results.

The results of our measurements in the crop lead to the conclusion that under normal conditions the reaction is nearly neutral. This neutrality can be more or less influenced by acid regurgitation of the stomach contents, which explains the more acid values obtained by some writers.

FARNER $(1942 b)$ was the first to establish that the $\mathrm{pH}$ of the stomach contents undergoes a rapid change after death, becoming less acid.

We could almost completely reduce the difference between values obtained in vivo and post mortem by being very careful in introduing the electrode in the digestive tract.

The possibility of a favourable action of pepsin and the location of $\mathrm{IICl}$ formation in the proventriculus are discussed.

It was determined that the reaction is acid over the whole digestive tract of fowls.

We have often obtained a slightly alkaline reaction in the intestine. Such a medium is propitious for the pancreatic enzymes.

The caeca have a $\mathrm{pH}$ of about 7 .

\section{RÉFÉRENCES BIBLIOGRAPHIQUES}

AscicratF D. W., 1933. Effects of Milk Products on the pII of Intestinal Contents of Domestic Fowl. Poult. Sci, 12, 292-298.

Browse T. G., I922. Some observations on the Digestive System of the Fowl. J. Comp. Path. Ther., 35, I $2-32$.

Buckner G. D., Insko W. M. jr, Henry A. H., I944. Does Breed, Age, Sex or Laying Condition affect the $\mathrm{pH}$ of the Digestive System of Chickens? Poult. Sci., 23, $457-45^{8}$.

Buddenbrock W. von, 1956. Vergleichende Physiologie, vol. III, 380-394. Birkhauser Verlag - Basel und Stuttgart.

FARneR D. S., 1942 a. The Hydrogen Ion Concentration in Avian Digestive Tracts. Poult. Sci., 21, 445-

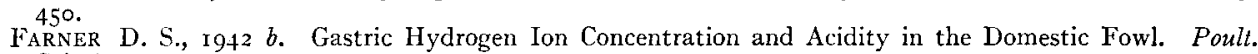
Sci., 22, 79-82.

Heller V. G., Penquite R., i936. Effect of the Mineral and Fiber on Avian Intestinal pH. Poult, Sci., 15, $397-399$.

HerpoL C., I959. Spijsvertering van Vogels : pH-metingen. Histologie van de Maag (thèse inédite).

HEWITT E. H., SCHELKOPF M. S., I95. pH Values and Enzymatic Activity of the Digestive Tract of the Chicken. Am. J. Vet. Research, Oct, 576-579.

Horton-Smith C. et Long P. L., I956. The Infection of Chickens with Histomonad Suspension. Parasilology, 46, 79-9o.

Hwang J. C., I96o. Effects of $\mathrm{pH}$, Various Proteolytic Enzymes, Amino Acids and other Substances on the Liggs and Larvae of Ascaridia galli. J.Parasitol., 46, 5, (Abstr.).

KERR W. B., Common B. H., I935. The Effect of Certain Acid Treatments for Coccidiosis on the H Ion Content of the Fowl's Intestine. Vet. J. 91, 309-3 I I.

Mc LaUginlin A. R., I931. Hydrogen Ion Concentration of the Alimentary Tracts of Fowl, Cat and Rabbit. Science, 73, 19I-192.

March B., TuckeY R., Biely J., 1958. The Effect of Diet on pH in the Intestinal Tract of Chickens. Poult. Sci., 37, 405-410.

MaYhew R. L., 1935. The Hydrogen Ion Concentration of the Digestive Tract of Fowl. J. Am. Vet. Med. Assoc., 86, I48-1 52 .

Musseite F. E., Blish M. J., Ackerson C. W., r933. Effect of Dietary and Environmental Factors on the $\mathrm{pH}$ of the Intestinal Tract. Poult. Sci, 12, I $20-\mathbf{r}_{3}$.

Robinson C. S., I935. The hydrogen Ion Concentration of the Contents of the Small Intestine. J. Biol. Chem., 108, 403-408.

SteinMETZER K., I924. Die zeitlichen Verhaltnisse beim Durchwandern von Futter durch die Magen-Darmkanal des Huhnes Pflugers Arch. ges. Physiol., 206, 500-5०5.

STURKIE P. D., I954. Avian Physiology, I64-184. Comstock Publishing Associates Ithaca N. Y.

Van Dobben W. H., I952. The Food of the Cormorants in the Netherlands. Ardea, 40, r-63.

Vonk H. J., Brink G., Postma N., I946. Digestion in the Stomach of Birds. I. The Acitidity in the Stomach of Young Chickens. Proc. Kon. Ned. Akad. Wet., 49, 972-982. 